\title{
Wpływ lasera biostymulacyjnego niskoenergetycznego i ćwiczeń usprawniających na zmniejszenie dolegliwości bólowych i poprawę funkcjonalną u pacjentów z chorobą zwyrodnieniową stawów kolanowych
}

\section{Effect of low-level laser therapy and exercise in reducing the symptoms of disease in patients with osteoarthritis of the knee}

\author{
Hanna Mosiejczuk', Karolina Bąk², Aleksandra Szylińska', Magdalena Ptak¹, Anna Mikołajczyk1, \\ Agnieszka Lubińska', Agnieszka Turoń1, Żaneta Ciosek', Iwona Rotter ${ }^{1}$
}

${ }^{1}$ Samodzielna Pracownia Rehabilitacji Medycznej Pomorskiego Uniwersytetu Medycznego w Szczecinie

ul. Żołnierska 54, 71-210 Szczecin

Kierownik: dr n. med. Iwona Rotter

${ }^{2}$ Koło Naukowe „Kinezis” przy Samodzielnej Pracowni Rehabilitacji Medycznej Pomorskiego Uniwersytetu Medycznego w Szczecinie

ul. Żołnierska 54, 71-210 Szczecin

Opiekun: dr n. med. Iwona Rotter

\begin{abstract}
SUMMARY
Introduction: Osteoarthritis is the most common disease of the joints contributing to the failure of movement. The disease mostly affects the older part of the population, and is associated with suffering and reduced quality of life. Knee osteoarthritis contributes to joint dysfunction of varying severity. These are common causes of chronic ailments limiting physical activity, which may even complicate the performance of activities of daily living. Low-level laser therapy is thought to have an analgesic effect, as well as a biomodulatory effect on the microcirculation. The aim of this study was to evaluate the effectiveness of low-level laser therapy on pain relief and functional improvement in patients with osteoarthritis of the knee. The effects of laser therapy alone and in combination with exercise were compared. Material and methods: 40 patients of mean age 65 years with knee osteoarthritis of both sexes were divided into two groups. Laser alone was used in group I $(\mathrm{n}=20)$ and laser combined with kinesistherapy was used in group II $(\mathrm{n}=20)$. All patients received the same dose of laser radiation, which was $3.0 \mathrm{~J} / \mathrm{cm}^{2}, 10 \mathrm{~Hz}$ $400 \mathrm{~mW}$. In both groups a series of 10 treatments was performed daily. VAS, ranges of motion in the knee joint, and the strength of the quadriceps and biceps femoris muscles were used as the
\end{abstract}

\section{STRESZCZENIE}

Wstęp: Choroba zwyrodnieniowa stawów jest najczęściej występującym schorzeniem stawów, przyczyniającym się do powstawania niepełnosprawności układu ruchu. Choroba dotyka przeważnie starszą część społeczeństwa, wiąże się z nią cierpienie i zmniejszenie jakości życia. Choroba zwyrodnieniowa stawu kolanowego przyczynia się do dysfunkcji stawów o różnym nasileniu. Często wywołuje przewlekłe dolegliwości ograniczające aktywność ruchową, które mogą nawet komplikować wykonywanie czynności dnia codziennego. Laser niskoenergetyczny wywiera działanie przeciwbólowe i biostymulujące na poziomie komórkowym. criteria of pain assessment in both groups. All measurements were taken before and after treatment.

Results: Significant pain reduction: I ( $p=0.00009, \mathrm{R}=0.68)$; II ( $p=0.00002, R=0.86)$, increased range of flexion in the knee: I ( $p=0.000001, R=0.90) ;$ II ( $p=0.00002, R=0.85)$, increased range of extension in the knee: I ( $p=0.042, R=0.87)$; II ( $p=0.0004$, $\mathrm{R}=0.9$ ) and increased strength of the quadriceps femoris muscle: I ( $p=0.03, R=0.77)$; II ( $p=0.0002, R=0.9)$ and the biceps femoris muscle: I $(p=0.04, R=0.80)$; II $(p=0.0007, R=0.91)$ were found in both groups after treatment. With the exception of flexion of the knee $(p=0.027 ; r=0.17)$, there were no statistically significant differences in other analysed parameters between the use of laser alone and laser therapy combined with exercise.

Conclusions: The use of laser in knee osteoarthritis reduces pain and improves the functional status of the patient. Laser therapy combined with kinesistherapy produces better therapeutic effects, and effectively improves the functional status of knee osteoarthritis. Exercise therapy applied in a series of 10 treatments is too short to significantly improve the functional status of the patient.

Key words: low-level laser therapy, osteoarthritis of the knee, kinesistherapy.
Celem pracy była ocena skuteczności lasera niskoenergetycznego w łagodzeniu dolegliwości bólowych i poprawie funkcjonalnej u pacjentów z chorobą zwyrodnieniową stawów kolanowych. Porównano zastosowania wyłącznie laseroterapii z działaniem lasera i ćwiczeń usprawniających.

Materiał i metody: Czterdziestoosobowa grupa pacjentów obojga płci, w wieku średnim 65 lat, z rozpoznaną chorobą zwyrodnieniową stawów została podzielona na dwie grupy. $\mathrm{W}$ grupie I $(\mathrm{n}=20)$ zastosowano laseroterapię, a $\mathrm{w}$ grupie II $(n=20)$ laseroterapię i kinezyterapię. Wszyscy badani zostali poddani takiej samej dawce energii promieniowania laserowego, która wynosiła 3,0 J/cm², $10 \mathrm{~Hz}, 400 \mathrm{~mW}$. W obu grupach seria 
wynosiła 10 zabiegów wykonywanych codziennie. Jako kryteria porównania dwóch grup przyjęto dolegliwości bólowe w skali VAS, zakresy ruchu w stawie kolanowym, siłę mięśni: czworogłowego i dwugłowego uda. Wszystkie pomiary zostały wykonane przed i po terapii.

Wyniki: W obu grupach po terapii uzyskano znaczne zmniejszenie dolegliwości bólowych: I ( $p=0,00009, R=0,68)$; II ( $\mathrm{p}=0,00002, \mathrm{R}=0,86)$, zwiększenie zakresu ruchu zgięcia w stawie kolanowym: I ( $=0,000001 ; \mathrm{R}=0,90)$; II ( $\mathrm{p}=0,00002$; $\mathrm{R}=0,85)$, zwiększenie zakresu ruchu wyprostu w stawie kolanowym: I ( $\mathrm{p}=0,042, \mathrm{R}=0,87)$; II ( $\mathrm{p}=0,0004, \mathrm{R}=0,9)$ oraz zwiększenie siły mięśnia czworogłowego: $I(p=0,03, R=0,77)$; II ( $p=0,0002, R=0,9)$ i dwugłowego uda: I $(p=0,04, R=0,80)$; II ( $p=0,0007, R=0,91)$. Za wyjątkiem ruchu zgięcia w stawie kolanowym ( $p=0,027 ; r=0,17)$ w pozostałych badanych parametrach nie zaobserwowano istotnie statystycznych różnic $\mathrm{w}$ zastosowaniu samej laseroterapii w stosunku do połączenia laseroterapii z ćwiczeniami.

Wnioski: Zastosowanie promieniowania laserowego w chorobie zwyrodnieniowej stawu kolanowego wpływa na zmniejszenie dolegliwości bólowych i poprawę stanu funkcjonalnego pacjenta. Laseroterapia skojarzona z kinezyterapią przynosi lepsze efekty terapeutyczne i efektywniej wpływa na poprawę stanu funkcjonalnego stawu kolanowego w chorobie zwyrodnieniowej. Nie zaobserwowano istotnie statystycznych różnic w działaniu samej laseroterapii, czy w połączeniu z kinezyterapią.

Słowa kluczowe: laser niskoenergetyczny, choroba zwyrodnieniowa stawów kolanowych, kinezyterapia.

\section{WSTEP}

Choroba zwyrodnieniowa stawów (osteoarthritis - OA) jest schorzeniem układu ruchu powszechnie występującym u osób starszych, przyczyniającym się do zwiększania poziomu przewlekłej niepełnosprawności w wielu krajach na całym świecie $[1,2,3,4]$. Jest schorzeniem przewlekłym, prowadzącym do destrukcji tkanki chrzęstnej stawowej, podchrzęstnych warstw tkanki kostnej, torebki stawowej, błony maziowej oraz tkanek miękkich okołostawowych. Razem z procesem destrukcyjnym współistnieje niedostateczny proces naprawczy charakteryzujący się zwiększeniem masy kostnej i tworzeniem osteofitów (wyrośli kostnych) na granicy chrzęstno-stawowej. W postaci zaawansowanej obserwuje się zniekształcenia końców stawowych kości doprowadzających do koślawego lub szpotawego ustawienia nasad kości, nadwichnięcia oraz zwichnięcia stawu. Powstający proces zapalny obejmuje torebkę stawową oraz okoliczne tkanki miękkie $[5,6,7,8,9]$. Przewlekła OA doprowadza do atrofii mięśni, spadku mobilności, utraty równowagi, przewlekłego bólu i niepełnosprawności fizycznej [1]. Pomimo że zmiany zwyrodnieniowe rozwijają się w każdym stawie maziówkowym, choroba zwyrodnieniowa dotyka najczęściej stawów biodrowych i kolanowych, dolnego odcinka kręgosłupa szyjnego i lędźwiowego oraz stóp i rąk $[7,10]$. Etiologia schorzenia jest wieloczynnikowa. Nadmierne przeciążenia, zaburzenia właściwości fizykochemicznych chrząstki i innych tkanek stawu, stany pourazowe i mikrourazy, wrodzone lub rozwojowe zaburzenia stawów, zaburzenia endokrynologiczne, czynniki metaboliczne, czynniki genetyczne, odkładanie soli wapnia, otyłość, neuropatie czy wysoka wartość mineralnej gęstości kości (bone mineral density - BMD) mogą być zaczątkiem choroby zwyrodnieniowej. Występowanie OA zwiększa się wraz z wiekiem, a zmiany zwyrodnieniowe dotyczą częściej kobiet niż mężczyzn. Również ich przebieg u kobiet jest cięższy. Predyspozycje rasowe zależą od różnic w anatomicznej budowie głowy i panewki stawowej, badania nie potwierdzają przewagi jednej rasy [7, 11, 12, 13].

Choroba zwyrodnieniowa stawów kolanowych (gonarthrosis, knee osteoarthritis - KOA) wg raportu Światowej Organizacji Zdrowia (World Health Organization - WHO) jest uznana za czwartą pod względem częstości przyczynę niepełnosprawności kobiet i ósmą mężczyzn [6, 14]. Według badań przeprowadzonych przez WHO w 1997 r. KOA występuje z częstością 6\% u osób starszych niż 30 lat i wzrasta o $40 \%$ u osób w wieku 70 lat lub starszych [15]. Ponad 30\% osób dorosłych z KOA powyżej 60. r.ż. doświadcza ograniczeń funkcjonalnych dotyczących czynności życia codziennego. Szacuje się, że do 2020 r. liczba osób z ograniczeniami funkcjonalnymi z powodu KOA wzrośnie do 11,6 mln osób [2, 16, 17]. Zachodzące zmiany degeneracyjne chrząstki stawowej doprowadzają do: występowania dolegliwości bólowych, sztywności, obniżenia wytrzymałości mięśni, ograniczenia ruchomości w stawach kolanowych powodującego zmniejszenie zdolności czynności funkcjonalnych. W wyniku działania tych czynników dochodzi do zaburzenia propriocepcji, zmniejszenia obronnych mechanizmów nerwowo-mięśniowych i zwiększenia niestabilności stawów, co funkcjonalnie przyczynia się do powstawania KOA $[2,18]$. W początkowych okresach może być leczona zachowawczo. W zaawansowanych okresach choroby leczeniem z wyboru jest endoprotezoplastyka. Skuteczność leczenia w dużym stopniu zależy od zaangażowania zespołu, w skład którego wchodzi lekarz i fizjoterapeuta, a przede wszystkim od samego pacjenta [19]. Głównym celem postępowania zachowawczego w KOA jest zapobieganie dolegliwościom bólowym i polepszenie wydolności czynnościowej stawu kolanowego. Leczenie farmakologiczne przyczynia się do zmniejszenia bólu, lecz stosowane przewlekle może doprowadzić do wielu działań niepożądanych. Leczenie pacjentów z KOA ma na celu zmniejszenie skutków choroby oraz spowolnienie jej postępu [20]. Zastosowanie znajdują zabiegi poprawiające ukrwienie i odżywienie tkanek, obniżające dolegliwości bólowe, usprawniające wydolność czynnościową kończyn i w efekcie poprawiające jakość życia. Leczenie KOA powinno być zastosowane kompleksowo i obejmować kinezyterapię, fizykoterapię, edukację pacjenta oraz leczenie farmakologiczne [21].

Leczenie fizjoterapeutyczne wykonuje się na podstawie diagnostyki i skierowania lekarskiego. Uprawnienia fizjoterapeutów ograniczone są do przeprowadzenia badania funkcjonalnego, zdolności wykonywania czynności dnia codziennego oraz do wykonania pomiarów zakresu ruchu, siły mięśniowej czy obwodów kończyn. Popularną metodą pomiaru siły mięśniowej jest test Lovetta, ponieważ jest on możliwy do przeprowadzenia 
w warunkach każdego oddziału klinicznego czy pracowni fizjoterapii. Od badającego oczekuje się dużego doświadczenia, szczególnie przy odciążaniu kończyny i stawianiu odpowiedniego oporu. Porównywanie siły mięśniowej w kończynie chorej i zdrowej pozwala kontrolować postępy w leczeniu, zaplanować i wdrożyć odpowiednie usprawnianie ruchowe [22, $23,24,25]$.

Badanie zakresu ruchu w stawach wykonuje się za pomocą goniometru, polega ono na określeniu wartości kątowej maksymalnego możliwego odchylenia od tzw. pozycji zerowej lub pośredniej. Prawidłowe zakresy ruchów zapisuje się wg ISOM (International Standard Ortopedic Measurement) [26, 27, 28, 29, 30, 31, 32].

Celem pracy była ocena skuteczności lasera biostymulacyjnego oraz ćwiczeń usprawniających, powodujących zmniejszenie dolegliwości bólowych oraz poprawę funkcjonalną u pacjentów z KOA.

\section{MATERIAŁ I METODY}

Badania wykonano w Samodzielnej Pracowni Rehabilitacji Medycznej Pomorskiego Uniwersytetu Medycznego w Szczecinie (PUM) w trybie ambulatoryjnym. Badaniem objęto 40 pacjentów w wieku średnim 65 lat, w tym 7 (17,5\%) mężczyzn i $33(82,5 \%)$ kobiety z KOA. Pacjenci zostali zakwalifikowani do badań na podstawie skierowania lekarskiego z rozpoznaniem: KOA (ICD - $10 \mathrm{M17}$ ). Badani zostali podzieleni losowo na dwie grupy 20-osobowe. W grupie I zastosowano jedną serię składającą się z 10 zabiegów laserem biostymulacyjnym niskoenergetycznym o mocy $400 \mathrm{~mW}$, w grupie II oprócz serii napromieniowania laserem zastosowano dodatkowo ćwiczenia usprawniające. Wszyscy badani poddani zostali takiej samej dawce energii promieniowania laserowego, która wynosiła $3,0 \mathrm{~J} / \mathrm{cm}^{2}$ o częstotliwości $10 \mathrm{~Hz}$, czas zabiegu wynosił $5 \mathrm{~min}$. W obu grupach seria wynosiła 10 zabiegów wykonywanych codziennie.

Kryteriami wykluczenia były: stwierdzona w wywiadzie choroba nowotworowa oraz przeciwwskazania do zastosowania promieniowania laserowego niskiej częstotliwości. Jako kryteria porównania dwóch grup badanych przyjęto dolegliwości bólowe, zakresy ruchu w stawie kolanowym, siłę mięśnia czworogłowego uda i mięśnia dwugłowego uda.

Postępy w leczeniu usprawniającym oceniano, sprawdzając dolegliwości bólowe za pomocą wizualnej skali analogowej (VAS). Zakres ruchu w stawie kolanowym sprawdzono, stosując goniometr. Ocenę mięśni czworogłowego i dwugłowego uda sprawdzono testem Lovetta, rozpoczynając wykonanie ruchu od stopnia trzeciego (ruch w pełnym zakresie z pokonaniem siły grawitacji).

\section{Postępowanie kinezyterapeutyczne}

Od 1. do 5. dnia usprawniania stosowano: ćwiczenia czynne w odciążeniu stawu kolanowego przez $15 \mathrm{~min}$, ćwiczenia czynne wolne wyprostu stawu kolanowego - 20 powtórzeń, ćwiczenia izometryczne mięśnia czworogłowego uda oraz mięśnia dwugłowego - 20 powtórzeń, cykloergometr - 15 min. Natomiast od 6. do 10. dnia zastosowano: ćwiczenia czynne w odciążeniu z oporem działającym na mięsień czworogłowy uda przez 15 min, ćwiczenia czynne w odciążeniu z oporem działającym na mięsień dwugłowy uda przez 15 min, ćwiczenia czynne wolne ruchu wyprostu w stawie kolanowym - 25 powtórzeń, ćwiczenia izometryczne mięśnia czworogłowego uda oraz mięśnia dwugłowego - 25 powtórzeń, cykloergometr - 15 min.

\section{Analiza statystyczna}

Analizę statystyczną przeprowadzono z użyciem statystyki opisowej, głównie średnich i odchyleń. Do sprawdzenia normalności rozkładu badanej grupy wykorzystano test ShapiroWilka, a w celu sprawdzenia jednorodności wariancji dla zmiennych ilościowych użyto testu Browna-Forsythe'a. W analizie statystycznej dla zmiennych zależnych w skali porządkowej użyto testu nieparametrycznego Wilcoxona, a dla zmiennych ilościowych użyto testu t-Studenta. Do analizy zmiennych niezależnych w skali porządkowej użyto testu Kruskala-Wallisa, a dla zmiennych ilościowych test $\mathrm{F}$ analizy wariancji. Korelację wykonano za pomocą współczynnika korelacji Spearmana. Za istotne statystycznie przyjęto wartości na poziomie $\mathrm{p}<0,05$. Analizę statystyczną wykonano przy użyciu licencjonowanego pakietu statystycznego Statistica 10.

\section{WYNIKI}

Uzyskane wyniki przedstawiono w tabeli 1. Średnie natężenie bólu w grupie I zmniejszyło się o ok. 65,6\%, zaś w grupie II o 70,2\%. Nie wystąpiły istotne statystycznie różnice pomiędzy grupą I a II w skali VAS przed terapią $(p=0,18 ; r=0,009)$ oraz w skali VAS po terapii $(p=0,26 ; r=0,39)$.

Zaobserwowano poprawę zakresu ruchu zgięcia w stawie kolanowym zarówno u pacjentów w grupie I, jak i II. Poprawa zakresu ruchu zgięcia w stawie kolanowym w I grupie wyniosła $8,7 \%$, zaś w grupie II 10,7\%. W obu grupach widoczna jest tendencja do zwiększania się zakresu ruchu w stawie kolanowym. Nie wystąpiły istotne statystycznie różnice pomiędzy grupą I a II zakresu ruchu zgięcia w stawie kolanowym przed terapią $(p=0,10 ; r=0,13)$, natomiast zaobserwowano istotnie statystycznie różnice ruchu zgięcia w stawie kolanowym po terapii pomiędzy obiema grupami $(p=0,027 ; r=0,17)$.

Zakres ruchu wyprostu w stawie kolanowym przedstawiono w stopniach, przy czym ujemna wartość oznacza, o ile przykurcz zgięciowy uniemożliwia pełen wyprost. W grupie I zakres ruchu wyprostu stawu kolanowego poprawił się średnio o 0,3\%, zaś w grupie II o 0,5\%. Nie wystąpiły istotne statystycznie różnice pomiędzy grupą I a II zakresu ruchu wyprostu w stawie kolanowym przed terapią ( $p=0,27 ; r=0,23)$ oraz ruchu wyprostu w stawie kolanowym po terapii pomiędzy obiema grupami $(\mathrm{p}=0,57 ; \mathrm{r}=0,09)$.

Zaobserwowano również wzrost siły mięśni działających na staw kolanowy. W grupie I średnia siła mięśnia czworogłowego uda po zastosowaniu wiązki laserowej wzrosła o 5\%, natomiast w grupie II o 13,7\%. Nie wystąpiły istotne 
TABELA 1. Ocena zależności między badanymi przed terapią i po terapii

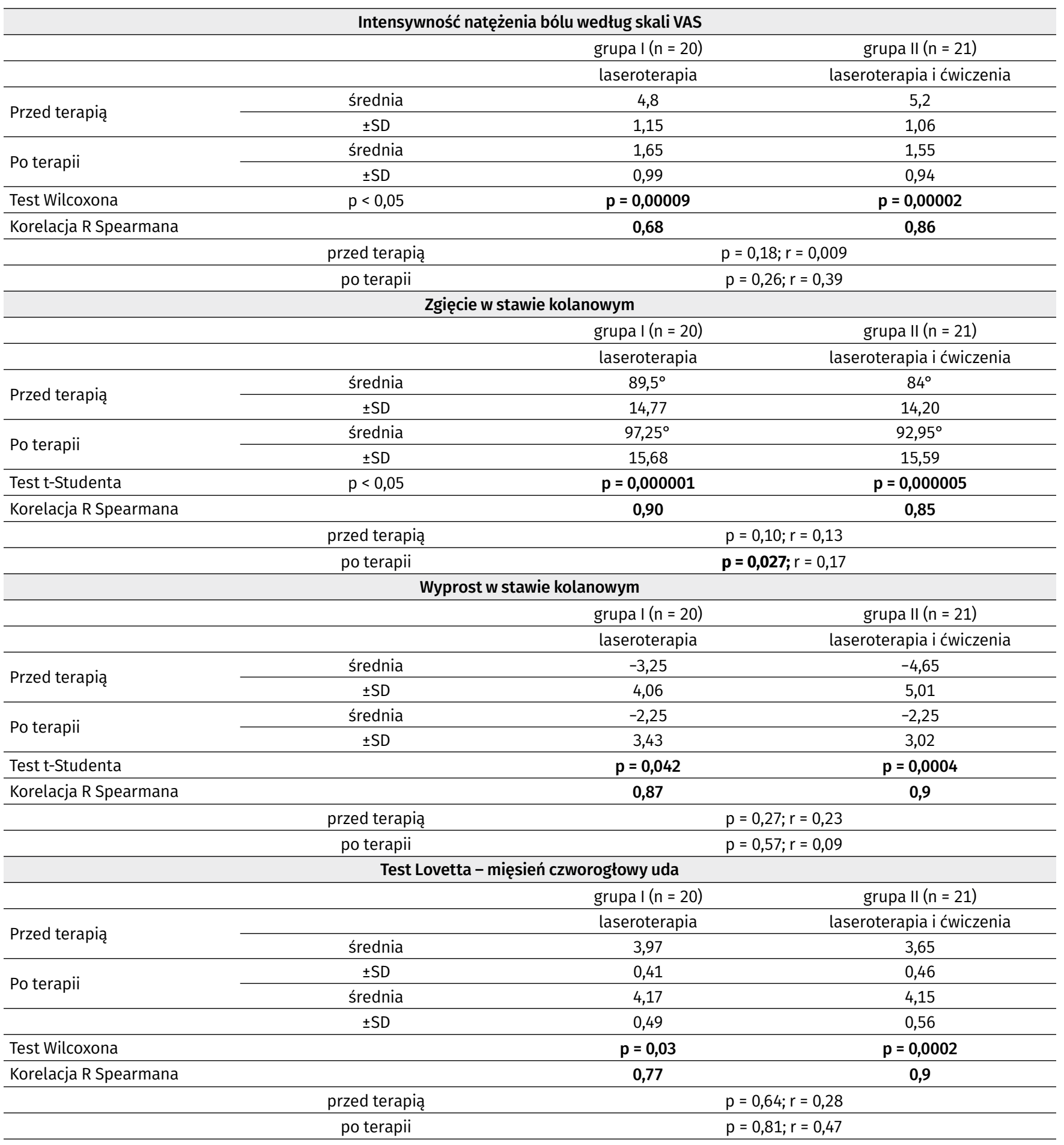

Test Lovetta - mięsień dwugłowego uda

\begin{tabular}{|c|c|c|c|}
\hline \multicolumn{4}{|c|}{ Test Lovetta - mięsień dwugłowego uda } \\
\hline & & grupa I $(n=20)$ & grupa II $(n=21)$ \\
\hline \multirow{2}{*}{ Przed terapią } & & laseroterapia & laseroterapia i ćwiczenia \\
\hline & średnia & 4,1 & 3,7 \\
\hline \multirow{3}{*}{ Po terapii } & $\pm \mathrm{SD}$ & 0,42 & 0,62 \\
\hline & średnia & 4,25 & 4,15 \\
\hline & $\pm \mathrm{SD}$ & 0,47 & 0,61 \\
\hline Test Wilcoxona & & $p=0,04$ & $p=0,0007$ \\
\hline \multirow[t]{3}{*}{ Korelacja RSpearmana } & & 0,80 & 0,91 \\
\hline & przed terapią & \multicolumn{2}{|c|}{$p=0,61 ; r=0,60$} \\
\hline & po terapii & \multicolumn{2}{|c|}{$p=0,07 ; r=0,41$} \\
\hline
\end{tabular}


statystycznie różnice siły mięśnia czworogłowego uda pomiędzy grupami przed terapią ( $\mathrm{p}=0,64 ; \mathrm{r}=0,28$ ) oraz po terapii $(\mathrm{p}=0,81 ; \mathrm{r}=0,47)$. W grupie I siła mięśnia dwugłowego uda poprawiła się średnio o 3,6\%, natomiast w grupie II wzrosła o 12,2\%. Nie wystąpiły istotne statystycznie różnice siły mięśnia dwugłowego uda pomiędzy grupami przed terapią $(p=0,61 ; r=0,60)$ oraz po terapii $(p=0,07 ; r=0,41)$.

\section{DYSKUSJA}

Choroba zwyrodnieniowa stawów jest powszechną chorobą układu ruchu, wywołującą silne dolegliwości bólowe, doprowadzającą do zwiększania stopnia niepełnosprawności na całym świecie. Choroba zwyrodnieniowa stawu kolanowego znacznie wpływa na zmniejszenie możliwości funkcjonalnych, zmniejszenie siły mięśni, zmniejszenie zakresu ruchu oraz zwiększenie dolegliwości bólowych w stawie kolanowym [2]. W wyniku starzenia się społeczeństwa oraz dużej liczby młodych osób uprawiających sporty obciążające stawy wraz z biegiem lat wzrasta liczba osób z KOA [33]. W celu poprawy funkcjonalności, zwiększenia zakresu ruchu, zwiększenia siły mięśniowej i zmniejszania dolegliwości bólowych można zastosować wiele różnych form i metod z dziedziny fizjoterapii (m.in. laseroterapię, elektroterapię, kinezyterapię, kinesiotaping) $[9,10,13,15,16$, $17,18,20,21,22,23,24,25,26,28,29,30,31,34,35,36,37,38,39,40]$.

Według wyników badań zastosowanie niskoenergetycznego promieniowania laserowego $\mathrm{w}$ dawce $3 \mathrm{~J} / \mathrm{cm}^{2}$ o częstotliwości $10 \mathrm{~Hz}$ i czasie trwania 5 min znacznie wpływa na poprawę stanu funkcjonalnego pacjenta oraz na zmniejszenie dolegliwości bólowych stawu kolanowego. Poprawę taką zaobserwowano w obydwu badanych grupach. Porównując wyniki pomiędzy obiema grupami, nie zaobserwowano istotnych statystycznie różnic, za wyjątkiem ruchu zgięcia stawu kolanowego $(p=0,027 ; r=0,17)$, co wskazuje na to, że nie ma większego znaczenia, czy u pacjentów zostanie zastosowana tylko laseroterapia, czy dodatkowo jeszcze kinezyterapia. Jednakże w grupie II, w której pacjenci mieli gorsze parametry, w badaniu wstępnym uzyskano lepsze wyniki po skończeniu terapii. Można wnioskować, że zastosowanie laseroterapii w połączeniu z kinezyterapią znacznie wpływa na poprawę funkcjonalności pacjentów ze zmianami zwyrodnieniowymi stawu kolanowego. Podobne wyniki uzyskali autorzy badań przedstawionych poniżej.

Lisiński twierdzi, że odpowiednia terapia fizjoterapeutyczna w KOA powinna składać się z kinezyterapii, mającej na celu przywrócenie odpowiedniego zakresu ruchu w stawie i zwiększenie siły mięśniowej, oraz działania fizykalnego ukierunkowanego na zlikwidowanie dolegliwości bólowych i poprawę elastyczności obkurczonych tkanek, co ułatwia tym samym kinezyterapię [34].

Zwolińska i wsp. podają, że zastosowanie promieniowania laserowego jest skuteczną terapią w schorzeniach narządu ruchu, w tym w chorobie zwyrodnieniowej. Zmniejszenie dolegliwości bólowych, zwiększenie zakresu ruchu i siły mięśniowej zauważono u 55-65\% pacjentów poddanych wyłącznie laseroterapii i u 82\% pacjentów, u których zastosowano w trakcie terapii także inne zabiegi fizykalne [35].

Fukuda i wsp. oszacowali skuteczność laseroterapii w połączeniu z ćwiczeniami w zmniejszeniu dolegliwości bólowych, poprawie funkcjonalności, zwiększeniu zakresu ruchu, zwiększeniu siły mięśniowej oraz poprawie jakości życia u pacjentów z KOA. Grupę 40 osób z chorobą zwyrodnieniową 2.-4. stopnia obu płci w wieku 50-75 lat podzielili losowo na dwie grupy: badaną (laser niskoenergetyczny o dawce $3 \mathrm{~J}$ i program ćwiczeń) oraz grupę placebo (placebo lasera i ćwiczenia). Dolegliwości bólowe oceniono za pomocą VAS, poziom funkcjonalności oceniono kwestionariuszem Lequesne'a, zakres ruchu stawu kolanowego goniometrem, siłę mięśni za pomocą dynamometru. Pomiary zostały wykonane przed zakończeniem i po zakończeniu terapii laserowej (3 tyg.) oraz po zakończeniu terapii ćwiczeniami (11 tyg.). Porównując obie grupy, uzyskano istotnie statystycznie różnice $w$ aktywności $(p=0,03)$. Nie zaobserwowano istotnych różnic statystycznych $(p>0,05)$ w innych zmiennych. W analizach wewnątrzgrupowych badani w grupie lasera uzyskali znaczną poprawę w stosunku do wartości wyjściowych: bólu $(p=0,001)$, zakresu ruchu $(p=0,01)$, funkcjonalności $(p=0,001)$ i aktywności $(p<0,001)$. Nie zaobserwowano znaczącej poprawy w wymienionych parametrach w grupie otrzymującej placebo [36].

Alghadir i wsp. zbadali działanie lasera niskoenergetycznego (gęstość energii $6 \mathrm{~J}$ w 1 punkcie przez $60 \mathrm{~s}$, moc $50 \mathrm{~mW}$, długość fali 850 nm, 2 razy w tygodniu przez 4 tyg.) w grupie 20 osób w porównaniu z grupą placebo $(n=20)$ na zmniejszenie dolegliwości i poprawę funkcjonalności stawu kolanowego u pacjentów z przewlekłą KOA. Zaobserwowali znaczną poprawę wszystkich ocenianych parametrów w stosunku do wartości wyjściowych. W grupie, w której był zastosowany laser, wykazano istotne różnice w zmniejszeniu dolegliwości bólowych zarówno w spoczynku, jak i w ruchu oraz zwiększenie funkcjonalności stawu kolanowego w porównaniu z grupą placebo [9].

Podobne wyniki przedstawili Hegedus i wsp. Zastosowali oni dawkę lasera niskoenergetycznego (830 nm, $50 \mathrm{~mW}, 6 \mathrm{~J} /$ punkt 2 razy w tyg. przez 4 tyg.) w grupie 27 pacjentów z KOA (grupa laser $n=18$, grupa placebo $n=9$ ) na zmniejszenie dolegliwości bólowych, obwodu stawów kolanowych, zwiększenie zakresu ruchu zgięcia. Uzyskali oni znaczną poprawę wyników we wszystkich ocenianych parametrach w grupie, w której zastosowano laser w porównaniu z grupą placebo [37].

Montes-Molina i wsp. na 152 pacjentach podzielonych na dwie grupy (po $\mathrm{n}=76$ ) z bólem stawu kolanowego porównali metodę interferencyjną ( 2 aplikatory na 1 staw) z metodą tradycyjną (1 aplikator na 1 staw) pod względem wpływu na zmniejszenie dolegliwości bólowych stawu kolanowego. W obu grupach 15 razy zastosowano laser o długości fali $810 \mathrm{~nm}$, mocy $100 \mathrm{~mW}$, w trybie ciągłym, $6 \mathrm{~J} /$ punkt oraz ćwiczenia izometryczne mięśnia czworogłowego uda. Wykazano statystycznie istotne zmniejszenie dolegliwości bólowych w całej grupie badanej $(\mathrm{p}=0,000)[38]$.

Stelian $i$ wsp. zastosowali LLLT u 50 pacjentów z OA. Grupę podzielono na 3 grupy terapeutyczne: I $(n=15)$ promieniowanie laserowe widzialne czerwone, II $(n=18)$ promieniowanie 
laserowe podczerwone, III ( $\mathrm{n}=17)$ placebo. U wszystkich pacjentów oceniano skalę dolegliwości bólowych oraz stopień niepełnosprawności na podstawie Disability Index Questionnaire przed, po oraz rok po zakończeniu terapii. Promieniowanie laserowe stosowano 2 razy dziennie przez $15 \mathrm{~min}$, przez $10 \mathrm{dni}$. Zastosowano falę ciągłą przez 7,5 min i falę przerywaną także przez 7,5 min. W grupie I zastosowano dawkę całkowitą 10,3 J $\left(5,1 \mathrm{~J} / \mathrm{cm}^{2}\right), \mathrm{w}$ grupie II - 11,1 $\mathrm{J}\left(5,6 \mathrm{~J} / \mathrm{cm}^{2}\right)$, w grupie placebo nie zastosowano żadnej terapii. Wykazali zmniejszenie dolegliwości bólowych i poprawę funkcjonalności pacjentów zarówno w grupie I, jak i II. Nie wykazano istotnie statystycznych różnic w związku z stosowaniem lasera czerwonego (red) czy podczerwonego (infrared). W grupie placebo nie uzyskano żadnej poprawy [39].

Rashoud i wsp. zbadali działanie lasera niskoenergetycznego i ćwiczeń u 49 pacjentów z KOA na zmniejszenie dolegliwości bólowych i poprawę jakości życia. Badanych podzielono na dwie grupy: grupa laser $(n=26)$ i grupa placebo $(n=23)$. Do terapii zarówno w grupie czynnej, jak i placebo (laser nie był aktywny) użyto lasera o długości fali $830 \mathrm{~nm}$, mocy $30 \mathrm{~mW}, 1,2 \mathrm{~J} /$ punkt przez 40 s przez 9 dni. Parametry oceniano na początku badania, w 5. dniu zabiegu, w ostatnim dniu serii, 6 tyg. po interwencji oraz 6 miesięcy po terapii. Według wyników badań wykazano znaczną poprawę wszystkich parametrów w grupie aktywnej lasera w porównaniu z grupą placebo [40].

W celu uzyskania poprawy funkcjonalnej stawu kolanowego wskazana jest dłuższa seria zabiegów laseroterapii niskoenergetycznej. Celem uzyskania lepszych efektów terapeutycznych terapia powinna być skojarzona z kinezyterapią. Głównym ograniczeniem badań była mała wielkość próby. Zasadne staje się więc przeprowadzenie badań na większej próbie przez dłuższy czas w celu oceny wpływu długoterminowego LLLT na zmniejszenie dolegliwości bólowych i poprawę jakości życia u pacjentów z KOA.

Badania fizjoterapeutyczne przeprowadzono w oparciu o metody subiektywne: test Lovetta, ocenę zakresu ruchu goniometrem. Nie można wykluczyć, że przeprowadzenie badań metodą bardziej obiektywną, np. dynamometr oraz sprzęt do oceny zakresu ruchu, mogłoby mieć wpływ na wyniki.

\section{WNIOSKI}

Zastosowanie promieniowania laserowego w chorobie zwyrodnieniowej stawu kolanowego wpływa na zmniejszenie dolegliwości bólowych i poprawę stanu funkcjonalnego pacjenta. Laseroterapia skojarzona z kinezyterapią przynosi lepsze efekty terapeutyczne i efektywniej wpływa na poprawę stanu funkcjonalnego stawu kolanowego w chorobie zwyrodnieniowej.

\section{PIŚMIENNICTWO}

1. Joshi A., Arora M., Zhang D., Wah M.D., Parvizi J.: A prototype evaluation of a computer-assisted physical therapy system for osteoarthritis. J Geriatr Phys Ther. 2008, 31 (2), 71-78.
2. Topp R., Brosky J.A., Pieschel D.: The effect of either topical menthol or a placebo on functioning and knee pain among patients with knee OA. J Geriar Phys Ther. 2013, 36 (2), 92-99.

3. Stanisławska-Bierna E.: Społeczne i ekonomiczne aspekty choroby zwyrodnieniowej stawów. Artykuł poglądowy. Pol Arch Med Wew. 2008, 118 (Suppl), 50-52.

4. Kaniewska K., Prokop I., Terlikowski R., Rysiak E., Kuryliszyn-Moskal A.: Choroba zwyrodnieniowa stawów jako problem ekonomiczny i społeczny w aspekcie leczenia zachowawczego. Pol Przegl Nauk Zdr. 2014, 2 (39), 102-108.

5. Muklewicz E., Sikorski S., Klimiuk. P., Lewandowski B., Kita K.: Diagnostyka radiologiczna w chorobie zwyrodnieniowej stawów. Próby klasyfikacji obrazu radiologicznego. Nowa Med. 2002, 2.

6. Kita K., Sierakowski S., Lewandowski B., Klimiuk P.A., Kita J., Muklewicz E.: Choroba zwyrodnieniowa stawów kolanowych - epidemiologia, diagnostyka i leczenie. Nowa Med. 2002, 2 (115), 27-30.

7. Leszczyński P., Pawlak-Buś K.: Choroba zwyrodnieniowa stawów - epidemia XXI wieku. Farm Współcz. 2008, 1, 79-87.

8. Aguiar G.C., Do Nascimento M.R., De Miranda A.S., Rocha N.P., Teixeira A.L., Scalzo P.L.: Effects of an exercise therapy protocol on inflammatory markers, perception of pain, and physical performance in individuals with knee osteoarthritis. Rheumatol Int. 2015, 35 (3), 525-531.

9. Alghadir A., Omar M.T., Al-Askar A.B., Al-Muteri N.K.: Effect of low-level laser therapy in patients with chronic knee osteoarthritis: a single-blinded randomized clinical study. Lasers Med Sci. 2014, 29 (2), 749-755.

10. Pop T., Hamerla K., Przysada G.: Czynniki wpływające na redukcję bólu u chorych zwyrodnieniową stawów kolanowych. Przegląd Medyczny Uniwersytetu Rzeszowskiego. 2007, 4, 335-345.

11. Zhang Y., Joanne M. Jordan J.M.: Epidemiology of osteoarthritis. Clin Geriatr Med. 2010, 26 (3), 355-369.

12. Litwic A., Edwards M., Dennison E.: Epidemiology and Burden of osteoarthritis. Br Med Bull. 2013, 105, 185-199.

13. Boener E., Ratajczak B., Chmiel M., Kuciel-Lewandowska J., Hawrylak A.: Ocena skuteczności krioterapii i magnetoterapii u chorych ze zmianami zwyrodnieniowymi stawów kolanowych. Acta Bio - Opica et Informatica Medica. 2010, 4 (16), 310-313.

14. Zimmermann-Górska I.: Leczenie choroby zwyrodnieniowej stawu kolanowego Aktualne (2003) zalecenia European League Against Rheumatism. Med Prakt. 2004, 3, 95-104.

15. Fioravanti A., Bacaro G., Giannitti C., Tenti S., Cheleschi S., Gui Delli G.M. et al.: One-year follow-up of mud-bath therapy in patients with bilateral knee osteoarthritis: a randomized, single-blind controlled trial. Int J Biometeorol. 2014, 59 (9), 1333-1343.

16. Thomas A., Eichenberger G., Kempton C., Pape D., York S., Decker A.M. et al.: Recommendations for the treatment of knee osteoarthritis, using various therapy techniques, based on categorizations of a literature review. J Geriatr Phys Ther. 2009, 32 (1), 33-38.

17. Currier L., Froehlich P., Carow S., McAndrew R.K., Cliborne A.V., Boyles R.E. et al: Development of a clinical prediction rule to identify patients with knee pain and clinical evidence of knee osteoarthritis who demonstrate a favorable short-term response to hip mobilization. Phys Ther. 2007, 87 (9), 1106-1119.

18. Kheshie A.R., Alayat M.S., Ali M.M.: High-intensity versus low-level laser therapy in the treatment of patients with knee osteoarthritis: a randomized controlled trial. Lasers Med Sci. 2014, 29 (4), 1371-1376.

19. Bielecki A., Jaźwa P., Kwolek A., Snela S.: Ocena funkcji kolana we wczesnym okresie po endoprotezoplastyce stawu i usprawnianiu pooperacyjnym. Przegląd Medyczny Uniwersytetu Rzeszowskiego. 2007, 2, 142-146.

20. Gasztych J., Puzder A., Gworys K., Pasternak K., Adamczewski T., Kujawa J.: Ocena porównawcza skuteczności terapeutycznej wybranych metod aplikacji promieniowania laserowego u osób z chorobą zwyrodnieniową stawu kolanowego. Kwart Ortop. 2012, 2, 257-269.

21. Kujawa J., Szmagaj-Piotrowska J., Gworys K., Leszczyńska A., Dudek K., Chrzanowska M. et al:: Wpływ wybranych zabiegów hydroterapeutycznych oraz kinezyterapii na wydolność czynnościową i dolegliwości bólowe stawów kolanowych u osób z chorobą zwyrodnieniową. Przegląd Medyczny Uniwersytetu Rzeszowskiego i Narodowego Instytutu Leków w Warszawie. 2011, 1, 40-42.

22. Zwolińska J., Kwolek A., Bienias W., Wolińska O.: Przydatność niektórych metod służących do diagnostyki i oceny efektów rehabilitacji pacjentów z zespołami neurologicznymi. Przegląd Medyczny Uniwersytetu Rzeszowskiego. 2009, 2, 154-161. 
23. Ogonowski A.: Diagnostyka w schorzeniach narządu ruchu. In: Rehabilitacja Medyczna. Ed. J. Kiwerski J. PZWL, Warszawa 2005.

24. Wilk-Frańczuk M., Tomaszewski W., Zemła J., Noga H., Czamara A.: Analysis of rehabilitation procedure following arthroplasty of the knee with the use of complete endoprosthesis. Med Sci Monit. 2011, 17 (3), CR165-CR168.

25. Lizis P.: Effect of spa physiotherapy on the range of motion and muscle strength in women with gonarthrosis. Ann Agric Environ Med. 2013, 20 (4), 784-786.

26. Kopacz Ł., Lubkowska A., Bryczkowska I., Skomro P., Kubala E., Kilijański M. et al.: Wartość terapeutyczna krioterapii miejscowej w leczeniu pacjentów z gonartrozą. Fizjoter Pol. 2013, 4 (13), 31-36.

27. Kilar J.Z., Lizis P.: Leczenie ruchem. Część I: Badanie narządu ruchu w rehabilitacji. Firma Handlowo-Usługowa „Kasper”, Kraków 2002.

28. Bennett D., Hanratty B., Thompson N., Beverland D.: Measurement of knee joint motion using digital imaging. Int Orthop. 2009, 33 (6), 1627-1631.

29. Cleffken B., van Breukelen G., Brink P., van Mameren H., Olde Damink S.: Digital goniometric measurement of knee joint motion. Evaluation of usefulness for research settings and clinical practice. Knee. 2007, 14 (5), 385-389.

30. Peters P.G., Herbenick M.A., Anloague P.A., Markert R.J., Rubino L.J.: Knee range of motion: reliability and agreement of 3 measurement methods. Am J Orthop (Belle Mead NJ). 2011, 40 (12), 249-252.

31. Nussbaumer S., Leunig M., Glatthorn J., Stauffacher S., Gerber H., A Maffiuletti $N$.: Validity and test-retest reliability of manual goniometers for measuring passive hip range of motion in femoroacetabular impingement patients. BMC Musculoskelet Disord. 2010, 11, 194-205.

32. Zembaty A.: Kinezyterapia. Firma Handlowo-usługowa „Kasper”, Kraków 2002.
33. Drużbicki M., Szczygielska D., Drużbicki M., Zajkiewicz K.: Epidemiologia i koszty leczenia zachowawczego chorych z chorobą zwyrodnieniową stawów biodrowych i kolanowych. Ortop Traumatol Rehb. 2007, 4 (6), 406-412.

34. Lisiński P.: Metody fizykalne w leczeniu bólu u chorych ze zwyrodnieniami stawów kolanowych. Ortop Traumatol Rehab. 2005, 7 (3), 317-321.

35. Zwolińska J., Weres A., Magoń G., Skalska-Izdebska R.: Wykorzystanie biostymulacji laserowej i światła VIP w leczeniu chorób narządu ruchu. Przegląd Medyczny Uniwersytetu Rzeszowskiego. 2007, 3, 277-279.

36. Fukuda V.O., Fukuda T.Y., Guimarães M., Wigderowitz C.: Short-term efficacy of low-level laser therapy in patients with knee osteoarthritis: a randomized placebo controlled, double-blind clinical trial. Rev Bras Ortop. 2011, 46 (5), 526-533.

37. Hegedus B., Viharos L., Gervain M., Galfi M.: The effect of low-level laser in knee osteoarthritis: a double blind, randomized, placebo-controlled trial. Photomed Laser Surg. 27 (4), 577-584.

38. Montes-Molina R., Madroñero-Agreda M.A., Romojaro-Rodríguez A.B., Gallego-Mendez V., Prados-Cabiedas C., Marques-Lucas C. et al.: Efficacy of interferential low-level laser therapy using two independent sources in the treatment of knee pain. Photomed Laser Surg. 2009, 27 (3), 467-471.

39. Stelian J., Gil I., Habot B., Rosenthal M., Abramovici I., Kutok N.: Improvement of pain and disability in elderly patients with degenerative osteoarthritis of the treated with narrow-band light therapy. J Am Geriatr Soc. 1992, 40 (1), 23-26.

40. Rashoud A.S., Abboud, Wang W., Wigderowitz C.: Efficacy of low-level laser therapy applied at acupuncture points in kneeosteoarthritis: a randomised double-blind comparative trial. Physiotherapy. 2014, 100 (3), 242-248. 